\title{
Toxic Action Reevaluation of Okadaic Acid, Dinophysistoxin-1 and Dinophysistoxin-2: Toxicity Equivalency Factors Based on the Oral Toxicity Study
}

\author{
Paula Abala $\quad$ M. Carmen Louzao ${ }^{a}$ Toshiyuki Suzuki ${ }^{b} \quad$ Ryuichi Watanabe $^{b}$ \\ Natalia Vilariño ${ }^{a}$ Cristina Carrera ${ }^{a}$ Ana M. Botana ${ }^{c}$ Mercedes R. Vieytes ${ }^{d}$ \\ Luis M. Botana
}

aDepartamento de Farmacología, Facultad de Veterinaria, Universidad de Santiago de Compostela, Campus Universitario, Lugo, Spain, bNational Research Institute of Fisheries Science, Japan Fisheries Research and Education Agency, Yokohama, Japan, 'Facultad de Ciencias, Universidad de Santiago de Compostela, Campus Universitario, Lugo, 'Departamento de Fisiología, Facultad de Veterinaria, Universidad de Santiago de Compostela, Campus Universitario, Lugo, Spain

\section{Key Words}

Oral toxicity $\cdot$ Okadaic acid $\cdot$ Dinophysistoxin-1 - Toxicity equivalency factor $•$ Ultrastructural effects $\cdot$ Toxin absorption

\begin{abstract}
Background/Aims:Okadaic acid (OA) and the structurally related compounds dinophysistoxin-1 (DTX1) and dinophysistoxin-2 (DTX2) are marine phycotoxins that cause diarrheic shellfish poisoning (DSP) in humans due to ingestion of contaminated shellfish. In order to guarantee consumer protection, the regulatory authorities have defined the maximum level of DSP toxins as $160 \mu \mathrm{g} \mathrm{OA}$ equivalent $\mathrm{kg}^{-1}$ shellfish meat. For risk assessment and overall toxicity determination, knowledge of the relative toxicities of each analogue is required. In absence of enough information from human intoxications, oral toxicity in mice is the most reliable data for establishing Toxicity Equivalence Factors (TEFs). Methods: Toxins were administered to mice by gavage, after that the symptomatology and mice mortality was registered over a period of $24 \mathrm{~h}$. Organ damage data were collected at necropsy and transmission electron microscopy (TEM) was used for ultrastructural studies. Toxins in urine, feces and blood were analyzed by HPLC-MS/MS. The evaluation of in vitro potencies of OA, DTX1 and DTX2 was performed by the protein phosphatase 2A (PP2A) inhibition assay. Results: Mice that received DSP toxins by gavage showed diarrhea as the main symptom. Those toxins caused similar gastrointestinal alterations as well as intestine ultrastructural changes. However, DSP toxins did not modify tight junctions to trigger diarrhea. They had different toxicokinetics and toxic
\end{abstract}


potency. The lethal dose $50\left(\mathrm{LD}_{50}\right)$ was $487 \mu \mathrm{g} \mathrm{kg}^{-1} \mathrm{bw}$ for DTX1, $760 \mu \mathrm{g} \mathrm{kg}$ $2262 \mu \mathrm{g} \mathrm{kg}^{-1} \mathrm{bw}$ for DTX2. Therefore, the oral TEF values are: OA $=1$, DTX1 $=1.5$ and DTX2 $=0.3$. Conclusion: This is the first comparative study of DSP toxins performed with accurate well-characterized standards and based on acute toxicity data. Results confirmed that DTX1 is more toxic than OA by oral route while DTX2 is less toxic. Hence, the current TEFs based on intraperitoneal toxicity should be modified. Also, the generally accepted toxic mode of action of this group of toxins needs to be reevaluated.

\section{Introduction}

Okadaic acid (OA) and its main structural analogues dinophysistoxin-1 (DTX1) and dinophysistoxin-2 (DTX2) [1] are globally distributed marine lipophilic phycotoxins produced by dinoflagellates of Prorocentrum and Dinophysis genera [2]. The toxins concentrate in shellfish due to their natural filter-feeding activity [2]. Ingestion of contaminated shellfish by human consumers leads to the diarrheic shellfish poisoning (DSP) characterized by quick onset of gastrointestinal symptoms.

$\mathrm{OA}$ and analogues reversibly inhibit serine/threonine protein phosphatases (PP) $[3,4]$ especially protein phosphatase 2A (PP2A) and as secondary targets protein phosphatase 1 (PP1) and protein phosphatase 2B (PP2B) [5]. DSP analogues have high but different affinity for protein phosphatases [5-7]. It was previously suggested that PPs inhibition was responsible for the diarrheic effect of $\mathrm{OA}$ and derivatives [8]. However, other actions not related to PP inhibition $[9,10]$, have been reported suggesting that the mechanism of toxicity of these compounds must be re-evaluated [11].

The enzyme-assay based on the inhibition of PP2A has been used as a routine screening tool in monitoring programs for the OA-group of toxins $[12,13]$. Data on the inhibitory potencies of different DSP toxins and their inhibition equivalency factors (IEF) in relation to the $\mathrm{OA}$ are necessary to the determination of DSP toxin contents in naturally contaminated mussel samples. The IEF based on the $\mathrm{IC}_{50}$ on PP2A activity of OA, DTX1 and DTX2 proposed were $1,0.6-1.6$ and 0.4-0.6 respectively $[14,15]$.

In order to protect consumers, the regulatory authorities have defined the maximum level of DSP toxins as $160 \mu \mathrm{g}$ of OA equivalent per kg of shellfish meat for human consumption [16] and have established a chromatographic method coupled to LC-MS/MS as the reference method for their detection [17]. Therefore, to estimate the total toxicity of seafood samples there is a need to know the relative toxicity of OA regulated analogues [18]. This requires determination of Toxicity Equivalency Factors (TEFs) defined as the ratio between the toxicity of each analogue and that of the reference compound within the same toxin group [19]. European Food Safety Authority (EFSA) Panel on Contaminants in the Food Chain (CONTAM) has established the TEF values 1.0, 1.0 and 0.6 for OA, DTX1 and DTX2, respectively [20] based on the relative inhibitory effect on protein PP2A and on acute intraperitoneal (i.p.) toxicity in mice.

However, in the absence of information about human intoxications, oral toxicity in animals has been recognized as the reference data for TEF estimation [13]. Only a few studies reported values of oral toxicity of DSP toxins. The previously described lethal oral doses of OA were 400 [21] 600 [22] and between $1000-2000 \mu \mathrm{g} \mathrm{kg}^{-1}$ bw [23], with a described $\mathrm{LD}_{50}$ of $880 \mu \mathrm{g} \mathrm{kg}^{-1} \mathrm{bw}[24,25]$. Some studies have reported values of DTX1 lethal dose below $300 \mu \mathrm{g} \mathrm{kg}^{-1} \mathrm{bw}$ while others reported no deaths in mice at the oral dose $750 \mu \mathrm{g} \mathrm{kg}{ }^{-1} \mathrm{bw}[19$, 26-28]. Regarding DTX2 an oral $\mathrm{LD}_{50}$ of $2262 \mu \mathrm{g} \mathrm{kg}^{-1}$ bw has been recently established [29]. However, the quality of the marine toxins utilized in toxicological studies has been one of the largest sources of variation of the results reported in the literature [19]. Almost none of the previous data were obtained using certified reference materials (CRM) to assure the concentration and stability of the doses utilized.

Therefore, the goal of this study was to assess the acute oral toxicity of $\mathrm{OA}$ and DTX1 in mice in order to reevaluate the mode of toxic action and determine the $\mathrm{LD}_{50}$ that 
allow the establishment of oral TEF. Furthermore, the symptomatology associated to oral intoxication, organ damage and ultrastructural alterations were also evaluated together with the absorption and excretion dynamics, and potency of the DSP toxins as PP inhibitors. This study will contribute to improve the evaluation of risk assessment of $\mathrm{OA}$ and its analogues, with important economic consequences for producing areas with toxin profiles that show a prevalence of DSP compounds of lower toxicity.

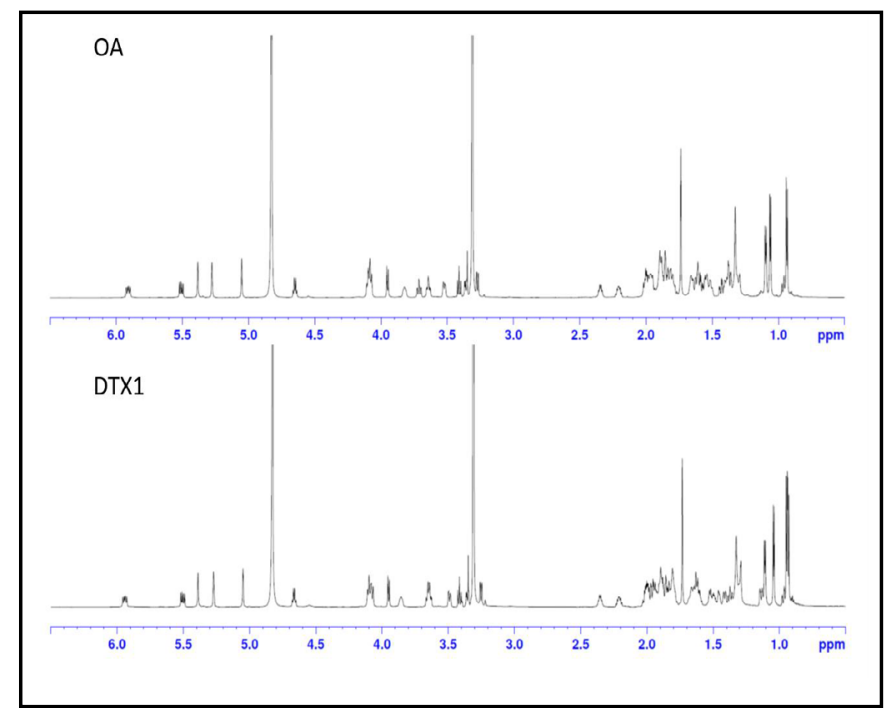

Fig. 1. ${ }^{1} \mathrm{H}-\mathrm{NMR}$ spectra of okadaic acid and dinophysistoxin-1 dissolved in $\mathrm{CD}_{3} \mathrm{OD}(800 \mathrm{MHz})$.

\section{Materials and Methods}

\section{Materials}

OA and DTX1 (National Research Institute of Fisheries Science (NRIFS) are from the Fisheries Research and Education Agency (Yokohama, Japan)).

OA and DTX1 isolated from toxic dinoflagellate Prorocentrum lima [30] were quantified by PULCON method [31] on the quantitative NMR with external standard. Purities (purity $>95 \%$ ) of both toxins were also confirmed by the NMR spectroscopy (Fig. 1). Purities were determined by the following equation:

Purity $=$ [Numbers of theoretical hydrogen atom] /[Numbers of hydrogen atom determined by qNMR] x $100(\%)$ Equ.1

Where numbers of theoretical hydrogen atom of OA and DTX1 are 68 and 70, respectively. Numbers of hydrogen atom of OA and DTX1 determined by ${ }^{1} \mathrm{H}-\mathrm{NMR}$ spectra of toxins dissolved in $\mathrm{CD}_{3} \mathrm{OD}(800 \mathrm{MHz})$ were 70.24 and 73.56, respectively. Because $\mathrm{OA}$ and DTX1 were dissolved in $\mathrm{CD}_{3} \mathrm{OD}$ which gives signals at 3.31 and $4.83 \mathrm{ppm}$, respectively, these signals were omitted to integrate the signals. The purities of OA and DTX1 calculated from the Equ. 1 were 96.8 and $95.2 \%$, respectively.

Other lipophilic toxins were not detected considering from ${ }^{1} \mathrm{H}$-NMR spectra of OA and DTX1.

DTX2 (purity $>98 \%$ ) was a certified reference material (CRM) supplied by Laboratorio CIFGA S.A. (Lugo, Spain). 5\% Glucose supplemented serum was obtained from B. Braun VetCare SA (Barcelona, Spain) and $0.9 \%$ saline solution from Grifols (Barcelona, Spain). The OkaTest kit was purchased from ZEULAB S.L (Zaragoza, Spain). All chemicals employed were HPLC or analytical grade from Sigma-Aldrich Química S.A. (Madrid, Spain).

Metabolic cages for single mouse were from Tecniplast (Buguggiate, Italy). Mice were fed with a rodent maintenance diet A04 (Scientific Animal Food and Engineering (SAFE) (Vannes, France).

\section{Animals and experimental conditions}

Swiss female mice (18-21 g) from the colonies of the University of Santiago de Compostela were used in the in vivo studies. They were housed in a temperature $\left(23 \pm 2{ }^{\circ} \mathrm{C}\right)$ and humidity $(60-70 \%)$ controlled room and maintained on a $12 \mathrm{~h} / 12 \mathrm{~h}$ light/dark cycle.

For the experimental procedure, mice were fasted overnight $(12 \mathrm{~h})$ with $5 \%$ glucose supplemented serum ad libitum. The next morning, after being weighed, mice received the toxin by gavage $\left(10 \mathrm{~mL} \mathrm{~kg}^{-1}\right)$ and were individually placed in metabolic cages for the following $24 \mathrm{~h}$ with free access to chow and water.

For administration, OA and DTX1 previously reconstituted with ethanol were diluted in $0.9 \%$ saline solution. Control mice receive the vehicle alone $\left(10 \mathrm{~mL} \mathrm{~kg}^{-1}\right.$ saline solution containing $2.5 \%$ ethanol). 


\section{Cellular Physiology Cell Physiol Biochem 2018;49:743-757 \begin{tabular}{l|l|l} 
and Biochemistry & $\begin{array}{l}\text { DOI: 10.1159/000493039 } \\
\text { Published onlIne: 30 August, } 2018\end{array}$ & $\begin{array}{l}\text { C) } 2018 \text { The Author(s). Published by S. Karger AG, Basel } \\
\text { www.karger.com/cpb }\end{array}$ \\
\hline
\end{tabular}}

Abal et al.: Toxicity Equivalency Factors For OA, DTX1 and DTX2

Acute oral toxicity was studied over a period of $24 \mathrm{~h}$ by a 4-level Up and Down Procedure previously described [29]. The starting dose was $1000 \mu \mathrm{g} \mathrm{kg}^{-1} \mathrm{bw}$ and the number of mice was increased at each dosage level (Fig. 2).

Animals that survive the whole experiment ( $24 \mathrm{~h}$ after toxin administration) were euthanized by $\mathrm{CO}_{2}$ inhalation. All animal procedures described in the manuscript were carried out in conformity to European legislation (EU directive 2010/63/EU) and Spanish legislation (Real Decreto 53/2013, Decreto 296/2008) and to the principles approved by the Institutional Animal Care Committee of the Universidad de Santiago de Compostela and Xunta de Galicia Code: 01/17/LU-002.

\section{Histopathological and Ultrastructural damage evaluation}

Samples of several organs (heart, lung, brain, spleen, liver, kidney, stomach and small and large intestine) were collected for histopathological evaluation in all animals immediately after death or after euthanasia in mice that survive the whole treatment. Macroscopic organ examination of all mice was done in the process of the organ extraction. Some samples were prepared for transmission electron microscopy (TEM) as was previously described [29].

\section{LC-MS analysis of mice samples}

Samples of urine, feces and blood of mice were analyzed by LC-MS/MS to evaluate toxin content.

Urine and feces sample extraction protocol was performed according to Abal et al. [29].

In the blood extraction protocol $800 \mu \mathrm{L} 75 \%$ methanol were added to $200 \mu \mathrm{L}$ intracardiac blood sample and vortexed for $1 \mathrm{~min}$. The mixture was transferred to an ultrafiltration spin column and centrifuged at $3000 \mathrm{rpm}$ for $30 \mathrm{~min}$. Then, the ultrafiltrated solution was evaporated and reconstituted with $200 \mu \mathrm{L}$ of methanol $100 \%$. Finally, samples were filtered by $0.22 \mu \mathrm{m}$ for $10 \mathrm{~min}$ at $14500 \times \mathrm{g}$ and $5 \mu \mathrm{L}$ were subjected to LC-MS/MS.

\section{LC-MS conditions}

Analyses were performed using a 1290 Infinity ultra-high performance liquid chromatography system coupled to a 6460 Triple Quadrupole mass spectrometer (Agilent Technologies, Waldbronn, Germany) as previously described [29]. The mass spectrometer was operated in MRM in negative mode, analyzing all OA and DTX1 transitions known. The transition with the highest intensity was used for quantification $(\mathrm{m} / \mathrm{z}$ $803.5>255.2 \mathrm{OA}, \mathrm{m} / \mathrm{z} 817.5>255.2 \mathrm{DTX} 1$ ), and one transition was used for confirmatory purposes (m/z 803.5 > 113.2 OA; $\mathrm{m} / \mathrm{z} 817.5>113.0$ DTX1).

All the parameters were optimized with accurate well-characterized OA and DTX1 standards in order to achieve the maximum level of sensitivity. Cell accelerator voltage (CAV) was $4 \mathrm{~V}$ and fragmentor $320 \mathrm{~V}$. Furthermore, collision energy (CE) value was optimized for each transition: $\mathrm{m} / \mathrm{z} 803.5>255.2(\mathrm{CE}=50 \mathrm{~V}$ ), $803.5>113.2(\mathrm{CE}=66 \mathrm{~V}$ ) for $\mathrm{OA}$ and $\mathrm{m} / \mathrm{z} 817.5>255.2(\mathrm{CE}=54 \mathrm{~V})$ and $817.5>113.0(\mathrm{CE}=70 \mathrm{~V})$ for DTX1.

OA and DTX1 standards were used for toxin calibration in the range $0.19-100 \mathrm{ng} / \mathrm{mL}$. The estimated limit of detection (LOD) based on a signal-to-noise ratio of $3(\mathrm{~S} / \mathrm{N}=3)$ and the limit of quantification (LOQ) considering a signal-to-noise ratio of $10(\mathrm{~S} / \mathrm{N}=10)$ of OA and DTX1 were $0.2 \mathrm{ng} / \mathrm{mL}$ and $1.3 \mathrm{ng} / \mathrm{mL}$ respectively.

\section{Serine/Threonine protein phosphatase 2A (PP2A) inhibition}

The PP2A inhibition assay was performed for the evaluation of the inhibitory potencies of OA, DTX1 and DTX2. To this propose we used the OkaTest kit in which PP2A is able to hydrolyze a specific substrate, yielding a product that can be detected at $405 \mathrm{~nm}$. OA, DTX1 or DTX2 inhibit the enzyme activity depending on their potency. In the test procedure $50 \mu \mathrm{L}$ of toxin and $70 \mu \mathrm{L}$ of the phosphatase solution were added in duplicate to a microwell plate. This mixture was equilibrated in an incubator for $20 \mathrm{~min}$ at $30^{\circ} \mathrm{C}$. Finally, 90 $\mu \mathrm{L}$ of the chromogenic substrate were added to each well and incubated for $30 \mathrm{~min}$ at $30^{\circ} \mathrm{C}$. Absorbance was measure by a Multi-mode Microplate Reader Synergy ${ }^{\mathrm{TM}} 4$ from Biotek (Biotek Instruments, Inc, Winooski, Vermont, USA) at $405 \mathrm{~nm}$. Three independent dose-response curves were done for each toxin.

\section{Data analysis}

Data were plotted as Mean \pm S.E.M. Statistical significance was determined by t-test for unpaired data and one-way ANOVA coupled to a post-hoc Dunnett test. $\mathrm{P}<0.05$ was considered for significance. 


\section{Results}

\section{Level Up and Down Procedure}

In vivo studies were performed with female mice following an optimized 4-level Up and Down Procedure where the toxins were administered by gavage to determine the OA and DTX1 oral $\mathrm{LD}_{50}$ (Fig. 2). The starting dose was $1000 \mu \mathrm{g} \mathrm{kg}{ }^{-1}$ bw for both toxin treatments and the doses were increased or decreased if mice mortality was lower or higher than $50 \%$ respectively (Table 1 and 2). Results are graphed as percentage of mice mortality versus the toxin dose administered (Fig. 3). The estimated oral $\mathrm{LD}_{50}$ for OA and DTX1 was 760 and $487 \mu \mathrm{g} \mathrm{kg}^{-1}$ bw respectively, calculated by a nonlinear regression fitting procedure (GraphPad Prism 5.0).

\section{Symptoms}

Table 3 reports the toxicity signs and symptoms of mice administered with DTX1 observed during the whole $24 \mathrm{~h}$ experiment. Toxicity signs and symptoms of mice treated with $\mathrm{OA}$ are reported in Table 4. Control mice remained healthy all the time while most of the treated mice showed inactivity and diarrhea. For diarrhea the elapsed time between the toxin administration and the appearance of the symptom is less than one hour and a half for both toxins and in most cases diarrhea disappeared between 3-4 h postdosification. After diarrhea, feces excretion was reduced in all mice treated with OA and DTX1. It should be noted that mice dosed with $250 \mu \mathrm{g}$ $\mathrm{kg}^{-1}$ bw DTX1, recovered the normal intestinal activity between $9-12 \mathrm{~h}$ after treatment.

During the experiment nonspecific signs such as apathy, piloerection and squint-eyes were also observed. Cyanosis, dyspnea and stand on hind legs were signs that appeared less frequent.

\section{Food and water consumption and body weight changes}

Mice were kept individually in metabolic cages during the whole experiment to allow monitoring of food and water intake of each mouse. Control mice maintained the food and water intake for the whole experiment and their body weight on average did not change. In contrast, mice treated with each toxin showed a statistically significant reduction in food and water consumption with a consequent decrease in body weight (Table 5 and 6). 
Anatomopathological examination

Necropsy of toxintreated mice was performed immediately after death of after euthanasia (in controls or mice that survived the whole treatment). Control mice showed stomachs filled with semi-digested food that also distends the small intestine (Fig. 4A and 5A). Large intestine was normally full of abundant solid feces and hearts were normal too. Nevertheless, mice that received $\mathrm{OA}$ or DTX1 showed alterations in these organs.
Table 2. Rate of mortality and survival times of mice after administration of DTX1 by gavage. The starting dose was $1000 \mu \mathrm{g} \mathrm{kg}^{-1} \mathrm{bw}$. Only one mouse survived $24 \mathrm{~h}$, so the dose for the second level was decreased to $500 \mathrm{\mu g} \mathrm{kg}^{-1} \mathrm{bw}$. At the second level five mice were included, Three mice died of a total of five treated with $500 \mu \mathrm{g} \mathrm{kg}^{-1} \mathrm{bw}$ DTX1, accordingly the dose was decreased to $250 \mu \mathrm{g} \mathrm{kg}^{-1} \mathrm{bw}$ for the third level. All mice survived with $250 \mathrm{\mu g} \mathrm{kg}^{-1} \mathrm{bw}$ DTX1 treatment, hence the dose for the fourth level was increased to $375 \mu \mathrm{g} \mathrm{kg}^{-1} \mathrm{bw}$. Of the nine mice that were included in the fourth level, none of them died with DTX1. Brackets indicate number of mice with the indicated survival time

\begin{tabular}{lcc}
\hline DTX1 Dose $\left(\mu \mathrm{kg}^{-1}\right)$ & Mortality & Survival times (h) \\
\hline 1000 & $2 / 3$ & $2: 34,8: 53,24: 00$ \\
500 & $3 / 5$ & $7: 27,6: 55,9: 14,24: 00(2)$ \\
375 & $0 / 9$ & $24: 00(9)$ \\
250 & $0 / 7$ & $24: 00(7)$ \\
\hline
\end{tabular}

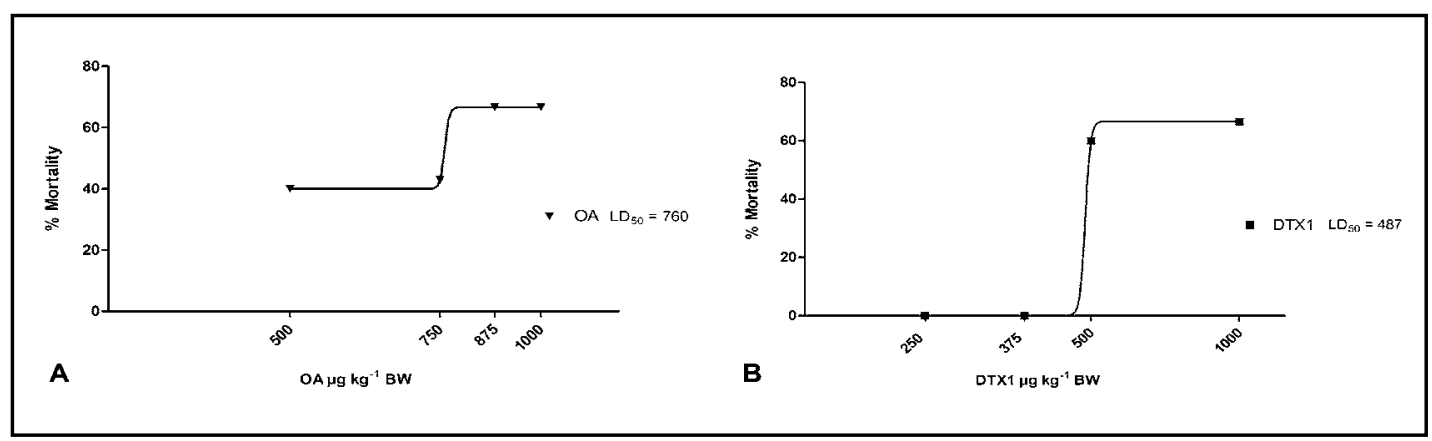

Fig. 3. Dose-dependent death induced by oral administration of OA (A) or DTX1 (B) within $24 \mathrm{~h}$ treatment in mice. $\mathrm{LD}_{50}$ are indicated.

Table 3. Symptoms registered after DTX1 administration. Ratio between mice with the symptom versus the total mice treated. For diarrhea the elapsed time between the toxin administration and the appearance of the symptom is also reported. Number in brackets represents the mice that have diarrhea at this time

\begin{tabular}{lcccc}
\hline \multirow{2}{*}{ Symptoms } & & & DTX1 dose $(\mu \mathrm{g} \mathrm{kg}-1)$ & \\
& 1000 & 500 & 375 & 250 \\
\hline Diarrhea & $2 / 3$ & $4 / 5$ & $6 / 9$ & $5 / 7$ \\
(time appearance) & $2: 51,12-24: 00$ & $0: 21,0: 24,0: 34,3: 00$ & $0: 40,0: 44,0: 46,1: 00(3)$ & $0: 20,0: 30,1: 00,1: 13,12-24: 00$ \\
Apathy & $3 / 3$ & $5 / 5$ & $8 / 9$ & $6 / 7$ \\
Piloerection & $1 / 3$ & $2 / 5$ & $4 / 9$ & $2 / 7$ \\
Squint-eyes & $3 / 3$ & $4 / 5$ & $7 / 9$ & $4 / 7$ \\
Spasms & $1 / 3$ & $1 / 5$ & $1 / 9$ & $2 / 7$ \\
Cyanosis & $2 / 3$ & $4 / 5$ & $6 / 9$ & $0 / 7$ \\
On hind legs & $0 / 3$ & $1 / 5$ & $2 / 9$ & $1 / 7$ \\
Dyspnea & $1 / 3$ & $0 / 5$ & $0 / 9$ & $0 / 7$ \\
\hline
\end{tabular}




\section{Cellular Physiology Cell Physiol Biochem 2018;49:743-757 \begin{tabular}{ll|l} 
DOI: 10.1159/000493039 & O 2018 The Author(s). Published by S. Karger AG, Basel \\
wwww.karger.com/cpb
\end{tabular}}

Abal et al.: Toxicity Equivalency Factors For OA, DTX1 and DTX2

Table 4. Symptoms registered after OA administration. Ratio between mice with the symptom versus the total mice treated. For diarrhea the elapsed time between the toxin administration and the appearance of the symptom is also reported. One mouse treated with the highest dose of $1000 \mu \mathrm{g} \mathrm{kg}^{-1} \mathrm{bw}$ OA that died before 3 $\mathrm{h}$ postdosification had no diarrhea. The other two mice showed fast diarrhea, before one hour and half. The recovery of normal intestinal activity occurred between $9-12 \mathrm{~h}$ after treatment in mice dosed with 750 and 850 $\mu \mathrm{g} \mathrm{kg}{ }^{-1}$ bw OA. As exceptional case, two mice with 500 and $750 \mu \mathrm{g} \mathrm{kg}^{-1}$ bw OA showed strong spasms in the neck area, moreover the last one was circling around itself. Number in brackets represents the mice that have diarrhea at this time

\begin{tabular}{|c|c|c|c|c|}
\hline \multirow{2}{*}{ Symptoms } & \multicolumn{4}{|c|}{ OA dose $\left(\mu \mathrm{g} \mathrm{kg}^{-1}\right)$} \\
\hline & 1000 & 875 & 750 & 500 \\
\hline Diarrhea & $2 / 3$ & $9 / 9$ & $4 / 7$ & $5 / 5$ \\
\hline (time & 0:48, & $0: 32,0: 33,0: 37,0: 40(2), 0: 41,0: 58$ & $0: 34,0: 56,0: 30$ & $0: 26,0: 32,1: 00,1: 00$, \\
\hline appearance) & $1: 19$ & $1: 00(2)$ & $1: 26$ & $1: 33$ \\
\hline Apathy & $3 / 3$ & $8 / 9$ & $7 / 7$ & $5 / 5$ \\
\hline Piloerection & $3 / 3$ & $5 / 9$ & $3 / 7$ & $1 / 5$ \\
\hline Squint-eyes & $3 / 3$ & $7 / 9$ & $4 / 7$ & $3 / 5$ \\
\hline Spasms & $1 / 3$ & $2 / 9$ & $2 / 7$ & $0 / 5$ \\
\hline Cyanosis & $2 / 3$ & $8 / 9$ & $4 / 7$ & $0 / 5$ \\
\hline On hind legs & $0 / 3$ & $4 / 9$ & $1 / 7$ & $3 / 5$ \\
\hline Dyspnea & $0 / 3$ & $0 / 9$ & $1 / 7$ & $0 / 5$ \\
\hline
\end{tabular}

Table 5. Body weight changes and food and water intake in OA treated mice during the $24 \mathrm{~h}$ experiment. The quantity of food and water volume was measured at the beginning and end of the experiment. Mean \pm S.E.M. $\left({ }^{* *} \mathrm{p}<0.01,{ }^{* * *} \mathrm{p}<0.001\right)$. The body weight reduction was not statistically significant in mice treated with $1000 \mu \mathrm{g} \mathrm{kg}^{-1}$ bw OA

\begin{tabular}{lcrr}
\hline OA Dose $\left(\mu \mathrm{gg}^{-1} \mathrm{BW}\right)$ & Body weight decrease (g) & Food consumption (g) & Water consumption (mL) \\
\hline Control & - & $3.98 \pm 0.16$ & $7.12 \pm 0.44$ \\
500 & $1.57 \pm 0.29^{* *}$ & $0.002 \pm 0.007^{* * *}$ & $0.4 \pm 0.24^{* * *}$ \\
750 & $2.03 \pm 0.3^{* * *}$ & $0.20 \pm 0.12^{* * *}$ & $0.33^{* * *} 0.19 * * *$ \\
875 & $1.95 \pm 0.27^{* * *}$ & $0.10 \pm 0.07^{* * *}$ & $0.7 * *$ \\
1000 & $0.81 \pm 0.74$ & 0 & 0 \\
\hline
\end{tabular}

Table 6. Body weight changes and food and water intake in DTX1 treated mice during the 24 h experiment. Mean \pm S.E.M. $\left(* p<0.05,{ }^{* *} p<0.001\right)$. The body weight reduction was not statistically significant in mice treated with the two highest doses of DTX1

\begin{tabular}{|c|c|c|c|}
\hline DTX1 Dose ( $\left.\mu \mathrm{g} \mathrm{kg}^{-1} \mathrm{BW}\right)$ & Body weight decrease (g) & Food consumption (g) & Water consumption (mL) \\
\hline Control & - & $3.76 \pm 0.20$ & $6.81 \pm 0.63$ \\
\hline 250 & $1.16 \pm 0.52 *$ & $0.81 \pm 0.35 * * *$ & $2.42 \pm 1.44 * * *$ \\
\hline 375 & $2.48 \pm 0.38 * * *$ & $0.07 \pm 0.06^{* * *}$ & $0.67 \pm 0.21 * * *$ \\
\hline 500 & $0.95 \pm 0.33$ & $0 * * *$ & $0 * * *$ \\
\hline 1000 & $0.59 \pm 0.92$ & $0.003 \pm 0.009 * * *$ & $0 * * *$ \\
\hline
\end{tabular}




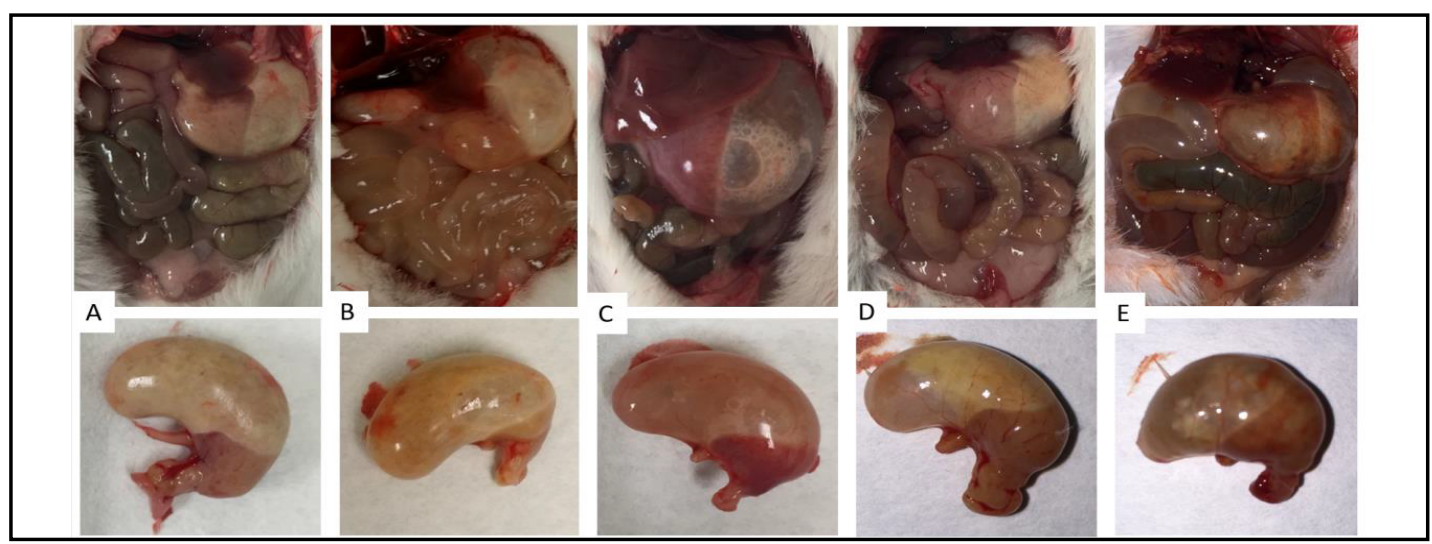

Fig. 4. Representative images of abdominal cavities of control mice (A) or mice treated with 250 (B), 375 (C), 500 (D) or $1000 \mu \mathrm{g} \mathrm{kg}^{-1}$ bw (E) DTX1. Detail of mice stomach is showed in the lower row for each corresponding dose. Note dilation of the small intestine and the liquid and gas content in stomach of treated mice.

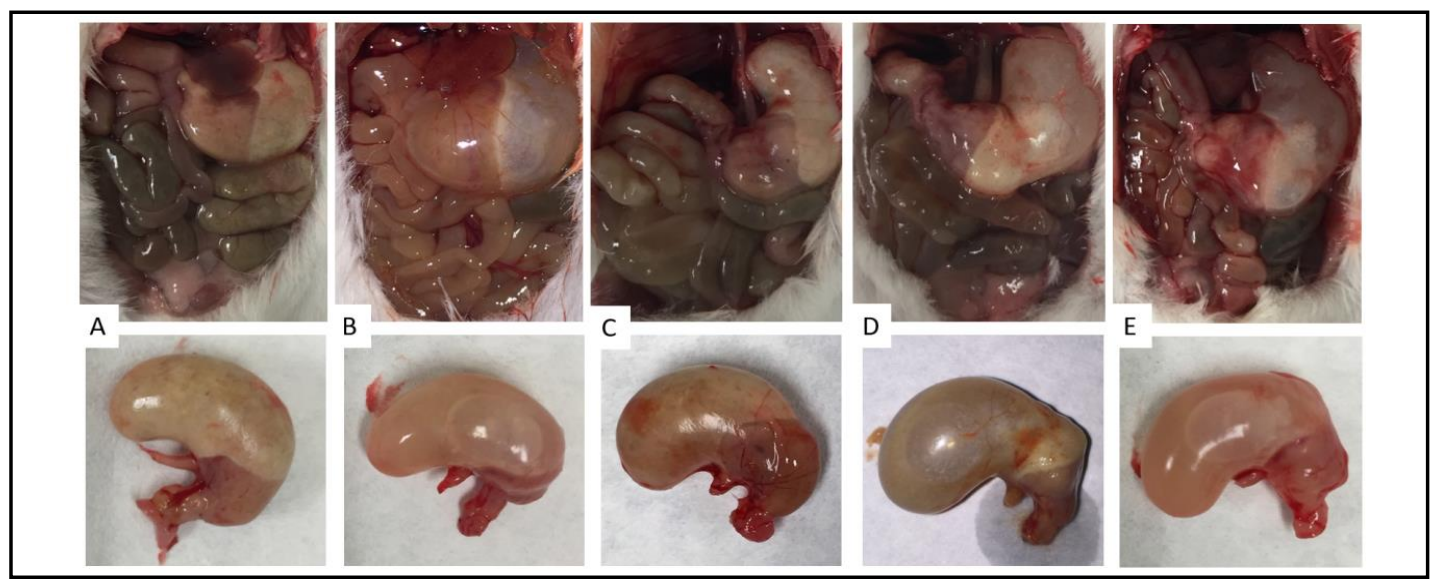

Fig. 5. Representative images of abdominal cavities of control mice (A) or mice treated with 500 (B), 750 (C), 875 (D) or $1000 \mu \mathrm{g} \mathrm{kg}^{-1} \mathrm{bw}$ (E) OA. Detail of mice stomach is showed in the lower row for each corresponding dose. Note dilation of the small intestine and the liquid and gas content in stomachs of treated mice.

Gastrointestinal tract and specially stomachs of mice administered with DTX1 or OA were swollen, with liquid and gas content (Fig. 4 B-E, Fig. 5 B-E). Only one mouse that received $1000 \mu \mathrm{g} \mathrm{kg}^{-1}$ bw $\mathrm{OA}$ showed no stomach content. Two mice treated with 750 and another mice that received $875 \mu \mathrm{g} \mathrm{kg}^{-1}$ bw OA presented bloody lumen content in stomach and small intestine, even reaching to the large intestine. One of the mice treated with $875 \mu \mathrm{g}$ $\mathrm{kg}^{-1}$ bw OA showed red wound and six mice administered with $375 \mu \mathrm{g} \mathrm{kg}^{-1}$ bw DTX1 showed redness of the gastric wall (Fig. 4 C). Almost all mice administered with OA presented fluid accumulation in middle and posterior part of the small intestine. Dilation of the small intestine was seen just in mice treated with $500 \mu \mathrm{g} \mathrm{kg}^{-1}$ bw DTX1 and in some mice that received different doses of $\mathrm{OA}$. In addition, the large intestine of mice treated with $1000 \mu \mathrm{g}$ $\mathrm{kg}^{-1}$ bw of OA or DTX1 showed swelling with watered feces.

About other organs (images not shown), reddish lungs were detected in mouse administered with 375, 500 and $1000 \mu \mathrm{g} \mathrm{kg} \mathrm{kg}^{-1}$ bTX1. Exceptionally some mice treated with $500 \mu \mathrm{g} \mathrm{kg}^{-1}$ bw DTX1 or OA also presented bloody brains. Mice administered with 875 $\mu \mathrm{g} \mathrm{kg}{ }^{-1}$ bw OA showed pale liver and kidney. The spleen was pale in one mouse treated with $500 \mu \mathrm{g} \mathrm{kg}^{-1}$ bw DTX1 and the liver was also pale in one mouse treated with $375 \mu \mathrm{g} \mathrm{kg}^{-1} \mathrm{bw}$ DTX1. Blood sampling by intracardiac puncture was difficult to carry out due to the stiffness of heart detected particularly in some mice treated with all OA doses and mice that received the highest DTX1 dose.

\section{KARGER}




\section{Cellular Physiology \begin{tabular}{c|c} 
and Biochemistry Published online: 30 August, 2018 & $\begin{array}{l}\text { OO } 2018 \text { The Author(s). Published by S. Karger AG, Basel } \\
\text { www.karger.com/cpb }\end{array}$
\end{tabular}}

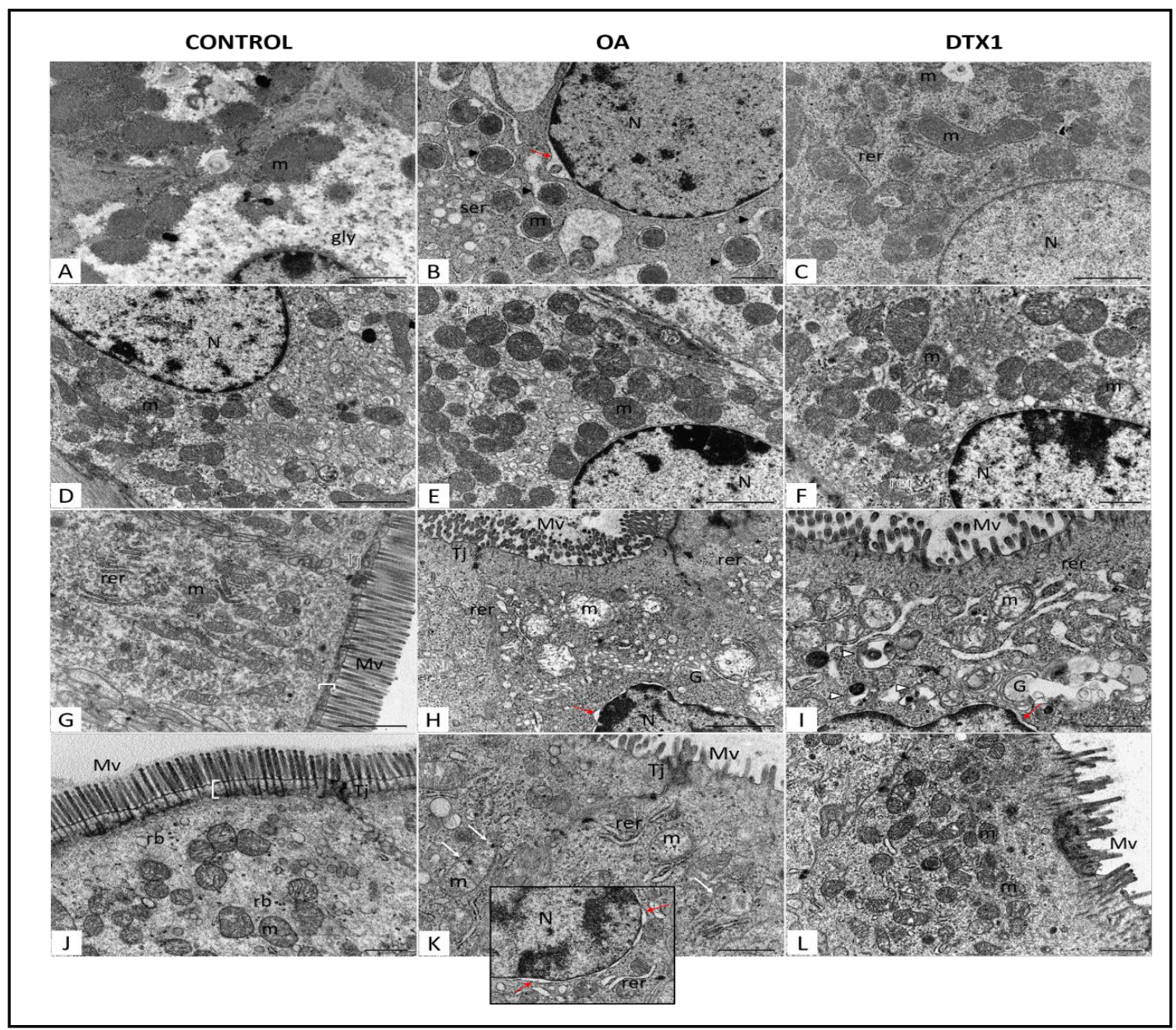

Fig. 6. Representative electron micrograph showing ultrastructure of cells form liver (A-C), stomach (D-F), small (G-I) and large intestine (J-L) from a control mouse (first column) and a mouse treated with $1000 \mu \mathrm{g} \mathrm{kg}^{-1} \mathrm{bw} \mathrm{OA}$ (second column) or $1000 \mu \mathrm{g} \mathrm{kg}^{-1}$ bw DTX1 (third column). Insert shows a view of the perinuclear space indicated by red arrows. Gly: glycogen granules, Mv: microvilli, m: mitochondria, N: nuclei, RER: rough endoplasmic reticulum, SER: smooth endoplasmic reticulum, Tj: tight junctions. Scale bar: $2 \mu \mathrm{m}$ (A, C, D, E, G, H), $1 \mu \mathrm{m}(\mathrm{B}$, F, I, J, K L).

\section{Ultrastructural examination}

Organ samples were collected from control and mice treated with OA or DTX1 after euthanasia at the end of the experiment $(24 \mathrm{~h})$. TEM analysis indicated that organs from control mice showed the normal ultrastructural organization, however some changes were detected in mice treated with the toxins that were more evident at the highest dose.

Liver cells of mice treated with OA (Fig. 6B) or DTX1 (Fig. 6 C) showed a decrease in glycogen granules (gly) and mitochondria (m) alterations that were detected as disruption of outer membrane or swelling. In liver cells of mice treated with OA mitochondria were surrounded by a membranous structure moreover cisternae of smooth endoplasmic reticulum (SER) were swollen. In the stomach cells only a slight swelling of some mitochondria was seen in the mouse treated with DTX1 (Fig. 6F). In the small intestine cells was recorded dilation of the rough endoplasmic reticulum (RER) in the epithelial lining together with mitochondria swelling. Those alterations were most remarkable in intestinal cells of mice treated with DTX1 (Fig. 6I) that displayed degenerated organelles inside autophagosomes (Fig. 6 I, white arrow head). In both toxins treatment induced similar widening of the perinuclear space (red arrows) in small intestine. However this effect was only detected in large intestine cells 


\section{Cellular Physiology and Biochemistry

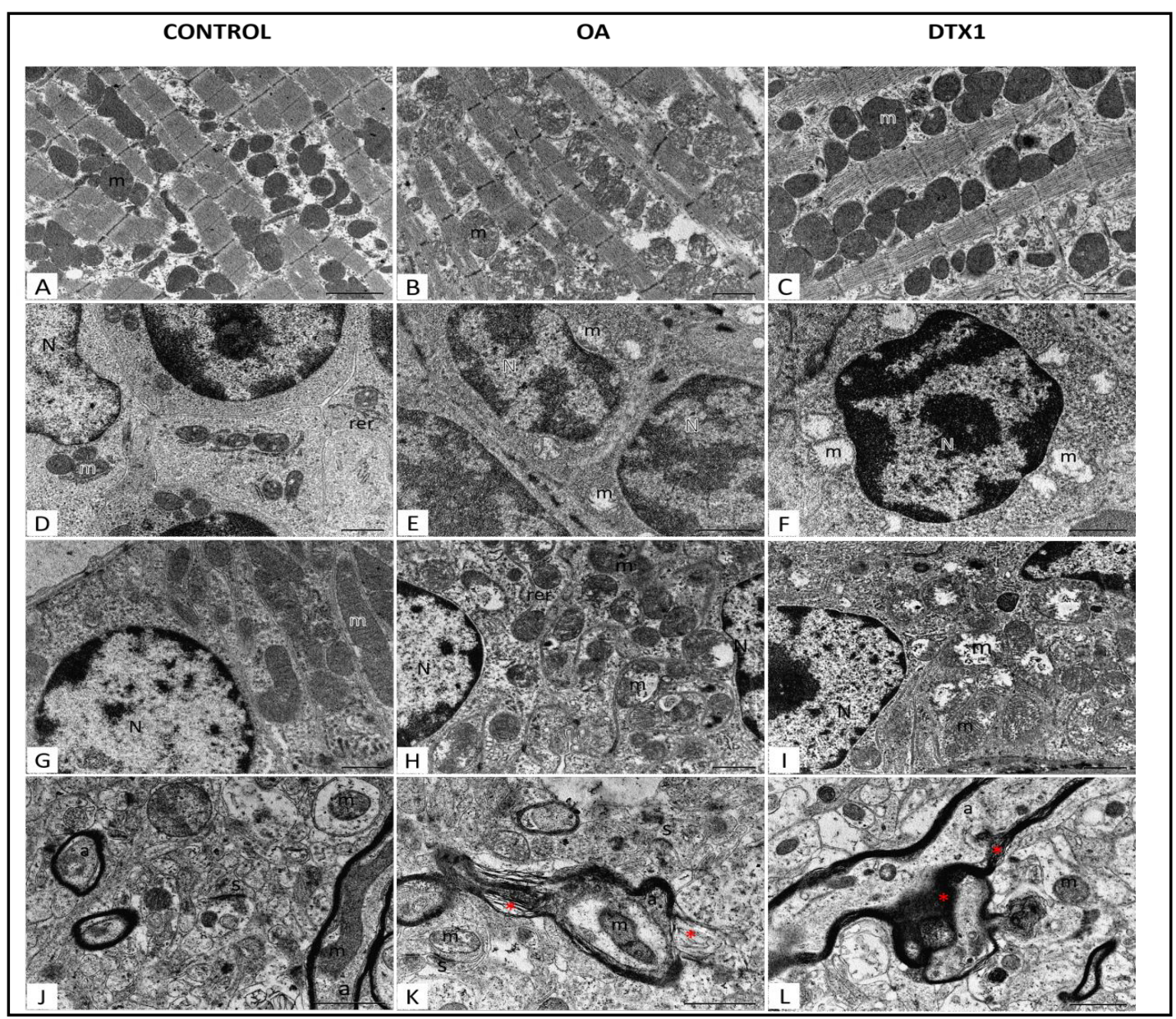

Fig. 7. Representative electron micrograph showing ultrastructure of cells from heart (A-C), spleen (D-F), kidney (G-I) and brain (J-L) from a control mouse (first column) and a mouse treated with $1000 \mu \mathrm{g} \mathrm{kg}^{-1} \mathrm{BW}$ OA (second column) or $1000 \mu \mathrm{g} \mathrm{kg}^{-1}$ bw DTX1 (third column). a: axon, m: mitochondria, N: nuclei, RER: rough endoplasmic reticulum *myelin. Scale bar: $2 \mu \mathrm{m}(\mathrm{A}, \mathrm{G}), 1 \mu \mathrm{m}(\mathrm{B}, \mathrm{C}, \mathrm{D}, \mathrm{E}, \mathrm{F}, \mathrm{H}, \mathrm{I}, \mathrm{J}, \mathrm{K}, \mathrm{L})$.

of OA-treated mice (Fig. 6 insert). In control samples long and abundant microvilli (Mv) emerge from a structured terminal web region (white bracket) (Fig. 6 G, J) meanwhile in small and large intestine of mice treated with OA or DTX1 microvilli were shortened, scarce and disorganized, with increase of the membrane and thickness of the terminal web (Fig. 6 $\mathrm{K}, \mathrm{L}$ ). However, tight junction structure (Tj) in both small and large intestine (Fig. 6H, I, K) remained undamaged. Formation of electron-dense granules (Fig. $6 \mathrm{~K}$, white arrows) was detected in mitochondria matrix of large intestine from OA treated mice (Fig. 6 K).

Heart cells of mice treated with $\mathrm{OA}$ showed disruption of mitochondria outer membrane (Fig. 7 B), whereas no alterations were detected in mitochondria of cardiomyocytes of mice that had received DTX1 (Fig. 6-C). Dilated RER was noted in mice treated with each toxin. Mitochondrial swelling was also seen in spleen (Fig. 7 E, F) and kidney cells (Fig. 7 H, I). In brain cells, lamellar separation and disintegration of myelin (red asterisk) were detected in axons (a) of mice treated with OA (Fig. 7-K) and DTX1 (Fig. 7-L). No ultrastructural changes were recorded in lungs (data not shown).

\section{LC-MS/MS analysis of mice samples}

OA and DTX1 were detected by LC-MS/MS analysis in mice urine, feces and intracardiac blood samples. In order to study the elimination kinetics, urine and feces (separated by the internal system of the metabolic cages) were collected at $1,3,6,9,12$ and $24 \mathrm{~h}$

\section{KARGER}




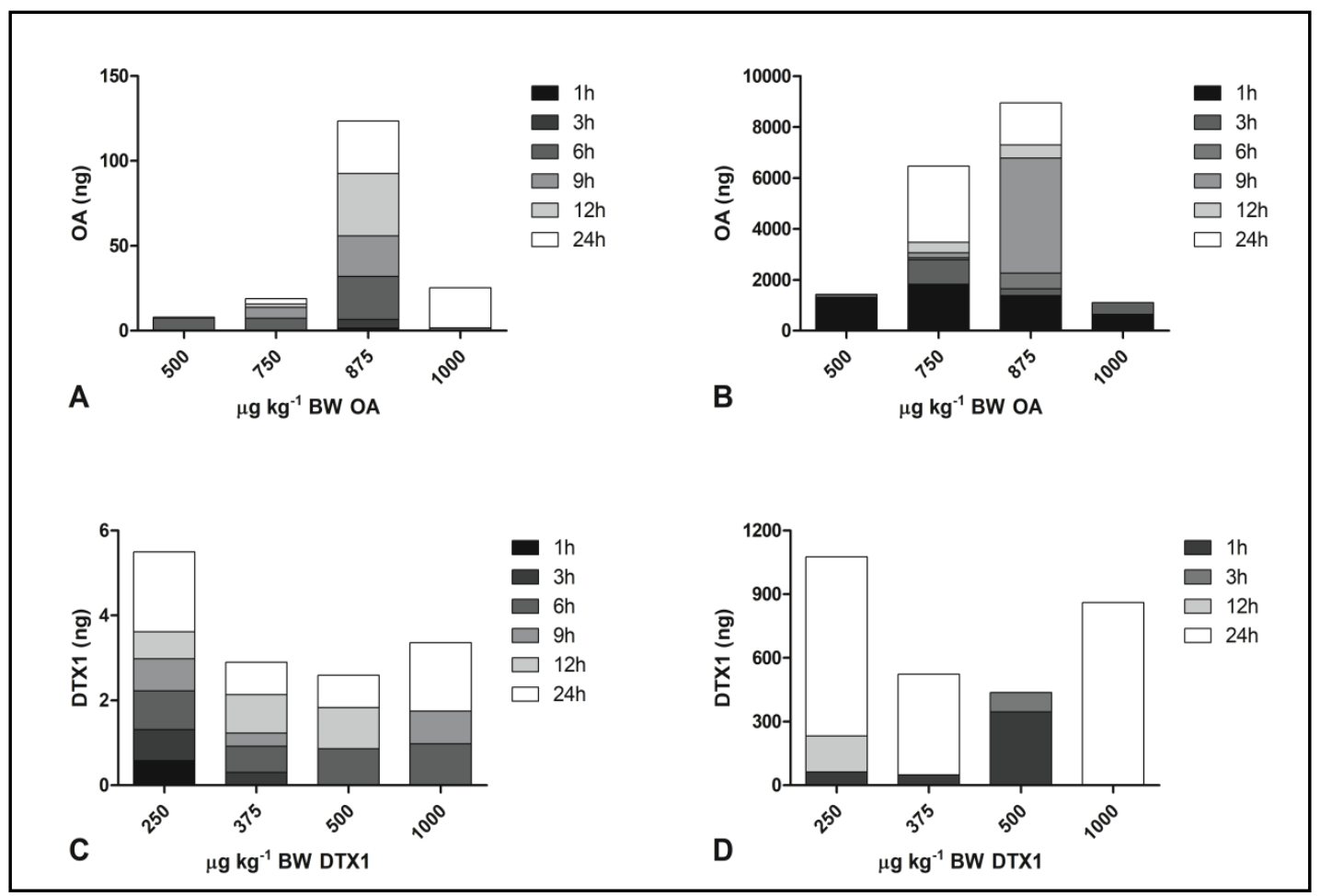

Fig. 8. Toxin excretion into urine (A and C) and feces (B and D) detected in samples collected from $1 \mathrm{~h}$ to $24 \mathrm{~h}$ after oral dosing in mice. Excretion of toxin in mice treated with $500,750,850$ or $1000 \mu \mathrm{g} \mathrm{kg}^{-1} \mathrm{bw} \mathrm{OA}(\mathrm{A}$ and B) or with 250, 375, 500 or $1000 \mu \mathrm{g} \mathrm{kg}^{-1}$ bw DTX1 (C and D) by oral gavage.

postadministration of toxins. In urine the quantities of OA and DTX1 detected were lower than in feces, yet the urine excretion of these toxins in mice was also important (Fig. 8). Analysis of urine showed the presence of $\mathrm{OA}$ in samples collected up to $24 \mathrm{~h}$ for each administration dose (Fig. 8A) always in higher amount than DTX1; although urine samples were not collected in two mice that received $1000 \mu \mathrm{g} \mathrm{kg}^{-1} \mathrm{bw}$ OA. DTX1 was quickly eliminated within the first $6 \mathrm{~h}$ with a slow but continuous excretion over the remainder of the collected time points particularly at the $250 \mu \mathrm{g} \mathrm{kg}^{-1}$ bw dose (Fig. 8C).

Following the oral doses, OA had a continuous and dose-dependent excretion in feces (Fig. 8B). These results suggest that some amount of toxin could be directly excreted without absorption.

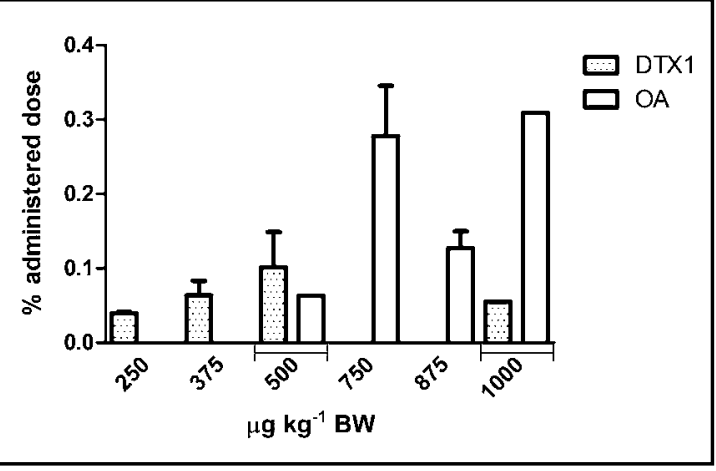

Fig. 9. Percentage of OA or DTX1 in blood samples collected $24 \mathrm{~h}$ after oral administration of the toxins. Percentage of oral DTX1 administered dose (dotted bars) in blood samples from mice treated with 250, 375, 500 or $1000 \mu \mathrm{g} \mathrm{kg}^{-1}$ bw by oral gavage. Percentage of oral OA administered dose (white bars) in blood samples from mice treated with $500,750,850$ or $1000 \mu \mathrm{g} \mathrm{kg}^{-1}$ bw by oral gavage. The highest amount of $\mathrm{OA}$ in feces was after $12 \mathrm{~h}$ post $875 \mu \mathrm{g} \mathrm{kg}^{-1}$ bw oral dose, but there was a lack of feces $6 \mathrm{~h}$ after treatment with $1000 \mu \mathrm{g} \mathrm{kg}^{-1}$ bw OA, therefore the amount of toxin detected in those samples was low. Excretion of DTX1 in feces was irregular (Fig. 8D), nevertheless the amount of DTX1 excreted was always lower than that of $\mathrm{OA}$ at the same administration doses. Both results suggested a higher intestinal absorption of DTX1 than OA. 


\begin{abstract}
Blood samples were collected by intracardiac puncture after mice death or euthanasia. Blood sampling was difficult in some mice treated with $\mathrm{OA}$ and mice that received the highest DTX1 dose. There were detectable amount of toxins in the blood over 24 h (Fig. 9). Differences in OA and DTX1 content in blood samples may be due to distinct absorption distribution and excretion rate between them.
\end{abstract}

\section{Inhibitory Potencies of DSP} toxins

Dose-response curves with OA, DTX1 and DTX2 were performed to evaluate the inhibitory potencies of these DSP toxins on the activity of PP2A (Fig. 10). The $\mathrm{IC}_{50}$ values were calculated for each toxin analogue by a nonlinear regression fitting procedure (GraphPad Prism 5.0) $\left(\mathrm{IC}_{50}\right.$ values are 2.27, 1.72 and $3.77 \mathrm{nM}$ for OA, DTX1 and DTX2 respectively indicating an order of potency of DTX1 > OA > DTX2.

\section{Discussion}

The guiding principles supporting the use of animals in toxicity studies are the Three Rs, replace, reduce and refine. Test Guidelines Programme of the Organization for Economic Cooperation and Development (OECD) has developed standardized methods following the Three Rs that are recommended by various regulatory agencies [32]. The method selected to compare the acute oral toxicity of DSP toxins in mice was a 4-level Up and Down Procedure. This is one of the OECD standardized methods in lien with the reduction in the number of animals. Results indicated that OA is less toxic than DTX1 with oral $\mathrm{LD}_{50}$ values of 760 and $487 \mu \mathrm{g} \mathrm{kg}^{-1}$ bw respectively, while DTX2 is the less potent with an oral $\mathrm{LD}_{50}$ of $2262 \mu \mathrm{g} \mathrm{kg}{ }^{-1}$ bw [29]. Those $\mathrm{LD}_{50}$ values were lower than previously reported and differences could be related to the quality of the marine toxins utilized [19, 24-28]. Based in these results the order of oral toxic potency is DTX1 > OA > DTX2 in agreement with the PP2A inhibitory potency. Nevertheless, this order of toxic potency do not correlate with the one based on i.p. toxicity $(\mathrm{OA}=\mathrm{DTX} 1>\mathrm{DTX} 2)$. Considering OA as the reference compound, the oral toxicity equivalency factors (TEFs) derived from $\mathrm{LD}_{50}$ values are: $\mathrm{OA}=1.0, \mathrm{DTX} 1=1.5$ and DTX2 $=0.3$ different from the current TEF values established by EFSA: OA = 1.0, DTX1 $=1.0$ and DTX2 = 0.6 [20]. Therefore, to evaluate the toxicity of a shellfish sample regardless of the DSP toxins present, oral TEFs proposed in the present study are more appropriate to protect human health than TEF based on i.p toxicity [18].

Symptoms reported after OA or DTX1 administration were similar to those previously described [24, 29]. It should be noted the fast appearance of diarrhea less than one hour and a half for both toxins and that this symptom in most cases disappeared 3-4 $\mathrm{h}$ postdosification.

Mice treated with OA and DTX1 showed macroscopic gastrointestinal alterations as dilation of stomach with gas and liquid indicating inhibition of gastric emptying [33]. Swelling and fluid accumulation in small intestine of mice treated with $\mathrm{OA}$ and dilation of large intestine in mice treated with the highest doses of OA and DTX1 supports affectation of 
gastrointestinal motility and secretion due to OA induced changes in NPY [10]. TEM analysis revealed that neither OA nor DTX1 changed tight junctions, therefore fluid accumulation in the intestine and diarrhea could not be related to increase in paracellular permeability along with tight junctions disruption as was previously suggested [11]. Intestine of mice administered with the highest dose of each toxin presented decreased enterocytes microvilli that were not seen after oral DTX2 administration [29]. Ultrastructural evaluation showed mitochondria in various stages of swelling that could be related to alteration of the villin that maintain mitochondrial integrity and also is involved in actin dynamics [34]. RER swelling in liver of mice treated with OA can be due to modifications in water and ions contents as well as to alteration on protein synthesis, translocation and accumulation induced by the toxin [35]. RER swelling seems to lead to the formation of phagophores [36] that engulf damaged organelles becoming autophagosomes present in small intestine of mice treated with DTX1. Thus, oral toxins administration may trigger a process of mitophagy that could be related with the reduction of glycogen seen in hepatocytes suggesting a reprogrammation of the metabolic profile to favor certain cellular processes [37].

The early appearance of diarrhea after acute oral administration of $\mathrm{OA}$ and the presence of the toxin in these feces indicated an elimination of part of administered toxin before absorption. However, gastrointestinal absorption and distribution of DTX1 occurs rapidly since it can be detected in urine in the first $3 \mathrm{~h}$, although some content remains in feces [24, 38]. About DTX2, excretion was greater in the last hours as was previously reported [29]. Absorption of toxins was demonstrated with the detection of OA and DTX1 in blood $24 \mathrm{~h}$ postdosification. Also, the dose-dependent time of death was consistent with plasma levels of toxins. These data suggested a different toxicokinetic pathway between OA, DTX1 and DTX2, even though the trigger of diarrhea was similar [29].

\section{Conclusion}

This is the first comparative study of the acute oral toxicity of DSP toxins by using accurate well-characterized standards. Symptoms, macroscopic organ alterations and ultrastructural changes were common to the DSP toxins, however they have different toxic potency and toxicokinetics. Their oral lethal potency is DTX1 $>$ OA $>$ DTX2. Based on the oral $\mathrm{LD}_{50}$ the TEFs values are: $\mathrm{OA}=1, \mathrm{DTX} 1=1.5$ and DTX2 $=0.3$. These oral TEFs are suitable for regulatory purposes to provide an estimate of the hazard of DSP toxins in edible seafood.

\section{Abbreviations}

OA (Okadaic acid); DTX1 (dinophysistoxin-1); DTX2 (dinophysistoxin-2); DSP (diarrheic shellfish poisoning); TEF (Toxicity Equivalency Factors); IEF (inhibition equivalency factors); bw (body weight); CRM (certified reference material).

\section{Acknowledgements}

The research leading to these results has received funding from the following FEDER cofunded-grants. From CDTI and Tehcnological Fund, supported by Ministerio de Economia, Industria y Competitividad, AGL2016-78728-R (AEI/FEDER, UE), ISCIII/PI16/01830 and RTC-2016-5507-2, ITC-20161072. From Conselleria de Cultura, Educacion e ordenacion academica Xunta de Galicia, 2017 GR GI-1682 (ED431C 2017/01). From European Union POCTEP 0161-Nanoeaters -1-E-1, Interreg AlertoxNet EAPA-317-2016, and H2020 778069-EMERTOX.

This research was partly supported by Council for Science, Technology and Innovation (CSTI), Cross-ministerial Strategic Innovation Promotion Program (SIP), "Technologies for 


\section{Cellular Physiology Cell Physiol Biochem 2018;49:743-757 \begin{tabular}{ll|l} 
DOI: 10.1159/000493039 & and Biochemistry 2018 The Author(s). Published by S. Karger AG, Basel \\
www.karger.com/cpb
\end{tabular}

creating next-generation agriculture, forestry and fisheries" (funding agency: Bio-oriented Technology Research Advancement Institution, NARO).

\section{Disclosure Statement}

The authors declare no conflicts of interest.

\section{References}

1 Suzuki T, Ota H, Yamasaki M: Direct evidence of transformation of dinophysistoxin-1 to 7-0-acyldinophysistoxin-1 (dinophysistoxin-3) in the scallop Patinopecten yessoensis. Toxicon 1999;37:187-198.

2 FAO: Marine Biotoxins, Food and Agriculture Organization of the United Nations, Rome, Italy, 2004.

-3 Bialojan C, Takai A: Inhibitory effect of a marine-sponge toxin, okadaic acid, on protein phosphatases. Specificity and kinetics. Biochem J 1988;256:283-290.

4 Cohen P: The structure and regulation of protein phosphatases. Annu Rev Biochem 1989;58:453-508.

5 Takai A, Murata M, Torigoe K, Isobe M, Mieskes G, Yasumoto T: Inhibitory effect of okadaic acid derivatives on protein phosphatases. A study on structure-affinity relationship. Biochem J 1992;284 (Pt 2):539-544.

6 Aune T, Larsen S, Aasen JAB, Rehmann N, Satake M, Hess P: Relative toxicity of dinophysistoxin-2 (DTX-2) compared with okadaic acid, based on acute intraperitoneal toxicity in mice. Toxicon 2007;49:1-7.

7 Twiner MJ, Doucette GJ, Pang Y, Fang C, Forsyth CJ, Miles CO: Structure-Activity Relationship Studies Using Natural and Synthetic Okadaic Acid/Dinophysistoxin Toxins. Mar Drugs 2016;14:207-2015.

8 Cohen P, Holmes CF, Tsukitani Y: Okadaic acid: a new probe for the study of cellular regulation. Trends Biochem Sci 1990;15:98-102.

-9 Valdiglesias V, Prego-Faraldo MV, Pasaro E, Mendez J, Laffon B: Okadaic acid: more than a diarrheic toxin. Mar Drugs 2013;11:4328-4349.

10 Louzao MC, Fernandez DA, Abal P, Fraga M, Vilarino N, Vieytes MR, Botana LM: Diarrhetic effect of okadaic acid could be related with its neuronal action: Changes in neuropeptide Y. Toxicol Lett 2015;237:151-160.

-11 Munday R: Is Protein Phosphatase Inhibition Responsible for the Toxic Effects of Okadaic Acid in Animals? Toxins 2013;5:267-285.

12 Garibo D, de la Iglesia P, Diogene J, Campas M: Inhibition equivalency factors for dinophysistoxin-1 and dinophysistoxin-2 in protein phosphatase assays: applicability to the analysis of shellfish samples and comparison with LC-MS/MS. J Agric Food Chem 2013;61:2572-2579.

13 FAO/WHO: Technical paper on Toxicity Equivalency Factors for Marine Biotoxins Associated with Bivalve Molluscs. Rome. 2016;108.

14 Huhn J, Jeffrey PD, Larsen K, Rundberget T, Rise F, Cox NR, Arcus V, Shi Y, Miles CO: A Structural Basis for the Reduced Toxicity of Dinophysistoxin-2. Chem Res Toxicol 2009;22:1782-1786.

15 Mountfort DO, Suzuki T, Truman P: Protein phosphatase inhibition assay adapted for determination of total DSP in contaminated mussels. Toxicon 2001;39:383-390.

16 Alimentarius C: Standard for Live and Raw Bivalve Molluscs; in Food and Agriculture Organization of the United Nations WHO (ed), 2008, CODEX STAN 292-2008, pp 1-7.

17 Union E: Commission regulation (EU) No 15/2011 of 10 January 2011 amending Regulation (EC) No 2074/2005 as regards recognised testing methods for detecting marine biotoxins in live bivalve molluscs. Off. J. Eur. Communities 2011;L6:3-9.

18 Louzao MC, Abal P, Vilariño N: Toxicity equivalence factor for regulated and non-regulated marine toxins. Current Opinion in Food Science 2017;18:64-70.

19 Botana L, Hess P, Munday R, Nathalie A, DeGrasse S, Feeley M, Suzuki T, Van den Berg M, Fattori V, Gamarro E, Tritscher A, Nakagawa R, Karunasagar I: Derivation of toxicity equivalency factors for marine biotoxins associated with Bivalve Molluscs. Trends Food Sci Technol 2017;59:15-24.

20 EFSA: Opinion of the Scientific Panel on Contaminants in the Food chain (CONTAM) on a request from the European Commission on marine biotoxins in shellfish-okadaic acid and analogues. EFSA J 2008;589:1-62. 


\section{Cellular Physiology Cell Physiol Biochem 2018;49:743-757 \begin{tabular}{ll|l} 
DOI: 10.1159/000493039 & $\begin{array}{l}\text { O 2018 The Author(s). Published by S. Karger AG, Basel } \\
\text { www.karger.com/cpb }\end{array}$
\end{tabular}

-21 Ito E, Satake M, Ofuji K, Higashi M, Harigaya K, McMahon T, Yasumoto T: Chronic effects in mice caused by oral administration of sublethal doses of azaspiracid, a new marine toxin isolated from mussels. Toxicon 2002;40:193-203.

22 Le Hegarat L, Jacquin AG, Bazin E, Fessard V: Genotoxicity of the marine toxin okadaic acid, in human Caco2 cells and in mice gut cells. Environ Toxicol 2006;21:55-64.

-23 Tubaro A, Sosa S, Carbonatto M, Altinier G, Vita F, Melato M, Satake M, Yasumoto T: Oral and intraperitoneal acute toxicity studies of yessotoxin and homoyessotoxins in mice. Toxicon 2003;41:783-792.

-24 Aune T, Espenes A, Aasen JA, Quilliam MA, Hess P, Larsen S: Study of possible combined toxic effects of azaspiracid-1 and okadaic acid in mice via the oral route. Toxicon 2012;60:895-906.

-25 Vieira AC, Rubiolo JA, Lopez-Alonso H, Cifuentes JM, Alfonso A, Bermudez R, Otero P, Vieytes MR, Vega FV, Botana LM: Oral toxicity of okadaic acid in mice: study of lethality, organ damage, distribution and effects on detoxifying gene expression. Toxins (Basel) 2013;5:2093-2108.

26 Ogino H, Kumagai M, Yasumoto T: Toxicologic evaluation of yessotoxin. Nat Toxins 1997;5:255-259.

27 Ito E, Terao K: Injury and recovery process of intestine caused by okadaic acid and related compounds. Nat Toxins 1994;2:371-377.

28 Munday R: Toxicology of seafood toxins: a critical review; in (Botana LM, ed) Seafood and Freshwater Toxins: Pharmacology, Physiology and Detection Boca Raton, CRC Press, 2014, pp. 197-290.

29 Abal P, Louzao MC, Cifuentes JM, Vilarino N, Rodriguez I, Alfonso A, Vieytes MR, Botana LM: Characterization of the dinophysistoxin-2 acute oral toxicity in mice to define the Toxicity Equivalency Factor. Food Chem Toxicol 2017;102:166-175.

30 Suzuki T, Watanabe R, Yoshino A, Oikawa H, Uchida H, Matsushima R, Nagai S, Kamiyama T, Yamazaki T, Kawaguchi M, Yarita T, Takatsu A: Preparation of diarrheic shellfish toxins (DSTs) and paralytic shellfish toxins (PSTs) by large algal culture and chemical conversion: 16th International Conference on Harmful Algae and International Society for the Study of Harmful Algae. Cawthron Institute, New Zealand and Wellington, 570 2014, pp 34-39.

-31 Watanabe R, Sugai C, Yamazaki T, Matsushima R, Uchida H, Matsumiya M, Takatsu A, Suzuki T: Quantitative Nuclear Magnetic Resonance Spectroscopy Based on PULCON Methodology: Application to Quantification of Invaluable Marine Toxin, Okadaic Acid. Toxins (Basel) 2016;8:E294.

32 OECD/OCDE: OECD Guidelines for the testing of chemicals 425. Acute Oral Toxicity-Up and Down Procedure. Organisation for Economic Co-operation and Development, Paris 2008;1-27.

33 Jensen TL, Kiersgaard MK, Sorensen DB, Mikkelsen LF: Fasting of mice: a review. Lab Anim 2013;47:225240.

34 Wang J, Wang YY, Lin L, Gao Y, Hong HS, Wang DZ: Quantitative proteomic analysis of okadaic acid treated mouse small intestines reveals differentially expressed proteins involved in diarrhetic shellfish poisoning. J Proteomics 2012;75:2038-2052.

35 Pryde JG, Farmaki T, Lucocq JM: Okadaic acid induces selective arrest of protein transport in the rough endoplasmic reticulum and prevents export into COPII-coated structures. Mol Cell Biol 1998;18:11251135.

-36 Tooze SA, Yoshimori T: The origin of the autophagosomal membrane. Nat Cell Biol 2010;12:831-835.

-37 Esteban-Martinez L, Sierra-Filardi E, McGreal RS, Salazar-Roa M, Marino G, Seco E, Durand S, Enot D, Grana O, Malumbres M, Cvekl A, Cuervo AM, Kroemer G, Boya P: Programmed mitophagy is essential for the glycolytic switch during cell differentiation. EMBO J 2017;36:1688-1706.

-38 Matias WG, Traore A, Creppy EE: Variations in the distribution of okadaic acid in organs and biological fluids of mice related to diarrhoeic syndrome. Hum Exp Toxicol 1999;18:345-350. 